\title{
Notas sobre (ou acordes para) o Noturno do Chile, a tormenta ruidosa de Roberto Bolaño*
}

\author{
Notes about (or chords for) By night in Chile, the noisy storm of Roberto Bolaño
}

\author{
DIEGO LOCK FARINA ${ }^{1}$ \\ 1 Universidade Federal do Rio Grande do Sul (UFRGS), Porto Alegre, RS, Brasil
}

\begin{abstract}
Resumo: Noturno do Chile, de Roberto Bolaño, funciona como uma autêntica máquina literária de denúncia, de afinada ironia e instigante trabalho estético. Tendo como narrador em primeira pessoa um padre extremamente envolvido com a ditadura de Pinochet, a obra opera uma tormenta ruidosa na forma que faz os signos estremecerem, ao passo que contra-assina a voz do próprio narrador que cria. O presente ensaio busca analisar as sutilezas formais que Bolaño desenvolve no controverso combate interno entre as memórias do narrador e a matéria narrada historicamente contextualizada, visando ainda entender como a noção de dom de ouvir, composta por Walter Benjamin e rearticulada por Jacques Derrida, é pertinente para uma leitura crítica do livro, que, por sua vez, invoca debates acerca do problema da alteridade, da afecção, da responsabilidade e, por fim, da ética ante a crueldade e a possibilidade da produção de uma poética da escuta na contemporaneidade.
\end{abstract}

Palavras-chave: Noturno do Chile; dom de ouvir; poética da escuta; Roberto Bolaño; alteridade.

\begin{abstract}
By night in Chile, by Roberto Bolaño, works as an authentic literary machine of denunciation, of intoned irony and instigating aesthetic labor. Having a priest extremely involved with Pinochet's dictatorship as a first-person narrator, the text operates a noisy storm in the form that makes the signs shake, while countersigns the voice of the narrator himself who creates. The present essay seeks to analyze the formal subtleties that Bolaño develops in the controversial internal struggle between the narrator's memories and the historically contextualized narrative matter, in order to understand how the notion of the gift for listening, composed by Walter Benjamin and rearticulated by Jacques Derrida, is pertinent for a critical reading of the book, which, in turn, invokes debates about the problem of alterity, affection, responsibility, and finally, ethics in the face of cruelty and the possibility of producing a poetics of listening in contemporary times.
\end{abstract}

Keywords: By night in Chile; gift for listening; poetics of listening; Roberto Bolaño; alterity.

* O presente trabalho foi realizado com apoio da Coordenação de Aperfeiçoamento de Pessoal Nivel Superior - Brasil (CAPES) - Código de Financiamento 001. 
"É preciso ser responsável. Eu disse isso a vida inteira. Você tem a obrigação moral de ser responsável por seus atos e também por suas palavras, inclusive por seus silêncios." BOLAÑO, Noturno do Chile, 2009.

Ao que concerne às possibilidades éticas do tratamento com a literatura, tendo em vista Roberto Bolaño, mas não apenas, do que se trata dar voz a um colaborador do horror? Isto é, pondo em perspectiva, o que é criar um narrador que, em primeira pessoa, à beira da morte, dentro da febre, rasteje por suas soturnas memórias que se desdobram, alegoricamente ou nem tanto, na memória de um país inteiro? Em Noturno do Chile, Sebastián Urrutia Lacroix é padre, poeta, professor e crítico literário, o Opus Dei mais liberal da república, segundo ele mesmo, e também um consagrado erudito no mais das vezes elogioso e conciliador, representante do civilizatório, à moda de seu sucessor, pai espiritual, latifundiário bon vivant e igualmente crítico literário das elites e do poder, a ave de rapina Farewell. Atormentado pela imagem de um jovem envelhecido enigmático que o acompanha em suas reflexões "insultando-o", possível desdobramento da própria consciência, Lacroix está submerso em um frágil circuito de duvidoso ressentimento que ainda não Ihe parece claro, sobretudo em meio a um Chile noturno. Nada é suficientemente claro para ser narrado. Contudo, mesmo assim, ao estilo das confissões, para não se cair na sarjeta, narra-se. Racista estrutural, misógino elementar, conivente com o fascismo de Pinochet - embora pense não se importar com política e nela, assim, jamais se envolver -, Lacroix, do melancólico ou contraditório remorso à nostalgia das aventuras de deleite letrado ou afetivo, narra passagens de sua vida que se embrenham a todo tempo à história recente chilena, cuja extensão dos impactos muito bem cabe à situação opressora da maioria dos países da América do Sul e Central da segunda metade do século XX, incluindo, evidentemente, o México, tão caro a Bolaño. É curioso, de certo modo, que determinada parcela da recepção do livro, formalmente treinada, academicamente familiarizada e assumidamente progressista, sinta-se agredida pelo empreendimento do autor, que, num primeiro momento, não à toa, quis que a obra se chamasse "Uma tormenta de merda", ou "Tempestade de merda", a depender da tradução ${ }^{1}$. O que torna a aversão pelo protagonista-narrador uma aversão estendida à obra que, por sua vez, pretende-se - assumamos de antemão que sim - enquanto uma revisitação crítica de vozes e silêncios que tramam o que conhecemos como história oficial do Chile? "Não existe, nas vozes que escutamos, ecos de vozes que emudeceram?" (BENJAMIN, 2010a, p. 223). Se a partir de Bertold Brecht e Walter Benjamin sabemos que, para narrar, é preciso distanciamento, é preciso vir de longe; que o narrador não está presente entre nós na sua atualidade viva, por seu caráter de virtualidade, o que faz com que venhamos a perceber Lacroix (em francês, oportunamente, a cruz) tão próximo, repulsivo, real e assustador, ainda que o mesmo se cubra de tamanha valoração moral e humanista? A epígrafe imperativa de G. K. Chesterton, nesse

\footnotetext{
Em entrevista, Bolaño comenta a questão do título: “O título que você pensou originalmente para Noturno do Chile foi "Tempestade de merda". Por que mudou? Basicamente porque meu editor, Jorge Herralde, não gostava, e depois de falar com ele repetidas vezes e dizer o nome do livro repetidas vezes, eu comecei a sentir nojo; tanta "Tempestade de merda" pode inclusive acabar com a paciência do próprio autor. Juan Villoro também desaconselhou o título original. E não me arrependo. Noturno do Chile expressa com maior fidelidade o que é o romance". Disponível em: < http:// miltonribeiro.sul21.com.br/tag/noturno-do-chile/ > . Acesso em: 09 ago, 2018.
} 
sentido, é reveladora: "Tire a peruca". Bolaño nos confecciona, portanto, um verdadeiro embuste. Lacroix narra silêncios exigentes de sofisticada atenção para escutá-los. Noturno do Chile parece filiarse secretamente à demanda que reivindica que ressuscitemos o "dom de ouvir e a comunidade de ouvintes" que Benjamin (2010, p. 205) alertava sobre seu desaparecimento e, sobretudo, sobre as alarmantes consequências dessa ameaça à vida. Se invocamos aqui o conceito de dom, de maneira certamente não transcendental, invocamos sob a configuração que Derrida (2001) acrescenta a Benjamin: o dom (doação) se coloca para além do agradecimento, ele não exige reciprocidade; nos gratificamos a nós mesmos quando doamos, doamo-nos ao escutar o outro, por exemplo, e essa simples consciência do dom anula o dom; o dom só terá lugar, portanto, onde ele parece impossível; eis a potência mais acontecimental de uma ética pela vida, o esforço da possibilidade impossível (impossível-ainda) de um dom que rompe a troca do dar-receber, o curso da história, o círculo da economia. Exercício retomado de alteridade intensiva, impossível: é preciso também ouvir o inimigo, o abjeto, ainda que por meio de um intento ficcional que tente representálo. É preciso que possamos - tenhamos o direito de - imaginar e sentir como o infame pensa, porta-se, defende-se, autoenganase, embora passando (ouvindo), enfim, por relatos atrozes dos mais terríveis e indigestos; ou seja, imaginar como ele seria - e sabemos, devido ao empreendimento da história que não é a dos vencedores, que este e outros de fato foram e são -, trata-se de uma tarefa nunca apenas ilustrativa. Para armar-se contra a proliferação de sujeitos desse feitio, é preciso materializá-los na possibilidade de suas realidades sensíveis, indo além das estereotipias figurativas que uma voz em terceira pessoa camufla, ou reifica, ou que simplesmente apresenta monstros segundo à regra (sem nenhum sentimento, apáticos, um outro que jamais nos tangencia, sem capacidade de pensamento, etc.). Nesta via, é pertinente pensar no termo francês entendre, que significa tanto "ouvir" como "entender", dupla articulação da qual Derrida se utiliza para introduzir a ideia de différance, e aqui nos vale igualmente à tentativa de reaver o dom de ouvir, em função do termo simultaneamente abranger a face sensível da escuta, a própria sensibilidade acústica dos afectos (afetar/ser afetado) e a face intelectual da compreensão racional, levando em conta tudo que se designa a partir do entendimento, sobretudo desde Kant. Dito isso, os personagens truculentos e polêmicos de Céline, a relativização de falar a respeito da pornografia infantil em Coetzee, a banalização do estupro e da sua transformação em pornô-amador na deep web em Pola Oloixarac, as memórias do torturador em García Márquez, os narradores falologocentristas de Henry Miller são exemplos dentre muitos desta contingência de acontecimentos literários que - distantes da estética do que se concebe como literatura de compromisso (pensemos nas acepções do serviço da literatura desde Sartre) ou da literatura propriamente autônoma, ao revés do engagement ${ }^{2}$, no rastro do Adorno das Notas de Literatura geram efeitos críticos/desconstrutivos muitas vezes mais profundos e persisten-

\footnotetext{
2 Ver em Theodor W. Adorno (1991) a distinção entre literatura engajada e obra autônoma em Engagement, dando destaque ao que o autor concebe como literatura política ao final do texto.
} 
tes, de fato desestabilizadores, porque inquietam os pressupostos metafísicos de certa configuração escritural esperada (historicamente modulada) para a abordagem de tais temas ou motivos ${ }^{3}$. Para Derrida (2014), que, diga-se de passagem, não vê o leitor como um consumidor ou espectador passivo, o experimento na língua, relacionado à paixão pela escritura - tanto do corpo, do desejo e da provocação -, fornece lugar à potência de atravessar discursos explicitamente reacionários conferindo a eles um poder de transgressão maior do que o dos pretensos textos "revolucionários" que se manifestam ainda a partir de formas convencionais, decorativas, quando não heroicizadas, romantizadas ou propagandistas. É claro que os grandes textos de compromisso declarado, marcantes pela sensibilidade estética que atingem, não entram nessa lógica, muito pelo contrário. Vista nesse entrecruzamento, a força do texto de Bolaño está em produzir uma contraassinatura em relação ao próprio narrador criado por ele. Uma contraforça à materialidade do livro-em-si, digamos, que se reafirma na exterioridade dos atos de uma leitura responsiva. Ou seja: confeccionar um narrador de estilo memorialista, confessional, privilegiado pelas circunstâncias conservadoras do regime

\footnotetext{
Jacques Derrida (2014, p.75), em Essa estranha instituição chamada literatura, revela uma passagem fundamental convergente a essa ótica: "Uma obra sobrecarregada de teses 'metafísicas' óbvias e canônicas pode, na operação de sua escrita, ter efeitos 'desconstrutivos' mais poderosos do que um texto que se autoproclama radicalmente revolucionário sem afetar em nada as normas ou os modos da escrita tradicional. Por exemplo, algumas obras que são altamente 'falocêntricas' em sua semântica, em seu significado intencional, em suas próprias teses, podem produzir efeitos paradoxais, paradoxalmente antifalocêntricos, pela audácia de uma escritura, que, de fato, perturba a ordem ou a lógica do falocentrismo, tocando no limite onde as coisas são revertidas (...) O mesmo ocorre de um ponto de vista político."
}

de exceção no Chile, trata-se, nunca sem combatente ironia, antes de mostrar (fazer mostragem) a realidade sensível de sujeitos que pensaram/pensam assim - e sim, há pensamento, pois não há bestas neste mundo movidas por pura animalidade irracional ou inconsciente - do que compactuar com seus ideais, vivências, ou então des-culpar-lo ou relativizá-lo à medida que Lacroix tenta se/nos convencer de que ele só esteve fazendo o que devia fazer. Dito assim, talvez, isso tudo pareça óbvio, ainda mais por termos notícia de quem é Roberto Bolaño, por sabermos acerca da sua trajetória de resistência, exílios, prisão e, logicamente, por conhecermos sua obra e sua postura de esquerda, crítica, deflagradora e denunciante. Mais à "antipoesia" sarcástica e subversiva de Nicanor Parra que à militância de Pablo Neruda, como bem se costuma acrescentar. Ao que concerne à estrutura da narrativa, fazem-se necessárias, antes que sigamos, algumas considerações formais. O livro inteiro se apresenta a partir de um longo e incômodo parágrafo, acompanhado, ao desfecho, por outro parágrafo com somente oito palavras comprimidas na frase que dá ponto final à obra: "E depois se desencadeia a tormenta de merda" (BOLAÑO, 2009, p. 118). A referência ao que seria o primeiro título pensado ao livro, como já comentado, assume o alastramento dessa brutal tormenta até nós. Passa-nos, inclusive, a questão do que fazer com ela, contra ela. Como se portar perante e fazer cessar. Reivindicar sua insignificância. Até seu desaparecimento. Todo o fluxo de consciência operado pelo narrador é, portanto, sinuoso, interpretativo e interpretável, foge ao controle de si mesmo; oscila entre comentários vorazes e apaziguadores a propósito do que vive, do que observa e do 
que prefere, em suposição, ignorar; a narrativa acaba por orientar uma espécie de torção pensante através de um tremendo esforço por velar certos assuntos, ao passo que se debruça demoradamente sobre outros, menos propícios ao dano. Como resultado disso, anuncia-se uma prosa de confusão mental, de ritmo muitas vezes poético (na camada do narrador) e antipoético (na espessura de Bolaño), na qual Lacroix varia entre saber e não saber ao certo sobre certas coisas, em função das nebulosidades da rememoração e da melancolia da experiência pretérita. Se, por um lado, isso não passa de um mecanismo de defesa, ou isenção premeditada, tal processo, por outro lado, leva o protagonista ao esgotamento do raciocínio, fazendo com que sutilezas perversas lhe escapem; o desalento se torna tédio e isso se dá no período justamente em que ele para de proferir suas missas, para de dar aulas e interrompe a escrita da poesia. $O$ abatimento e a desilusão crescem conforme crescem as ofensas diversas a respeito de sua escondida homossexualidade e de seu reacionarismo exasperado, assim como aumentam as intervenções do jovem envelhecido, ocasiões que fazem Lacroix confessar que nesse espaço de tempo teve sua moral atormentada. A defesa quase libidinosa de não ter memória para só ouvir o latejar do sangue $^{4}$, construção extremamente am-

\footnotetext{
4 A passagem é a seguinte: "Agora o jovem envelhecido me observa de uma esquina amarela e grita para mim. Ouço algumas das suas palavras. Diz que sou do Opus Dei. Nunca escondi isso, disse-lhe. Mas certamente ele também não me ouve. (...) Ele me sussurra, apoiado num cotovelo, enquanto minha cama navega pelos meandros da minha febre (...) Gostaria de dizer a ele que até os poetas do Partido Comunista Chileno morriam de vontade de que eu escrevesse alguma coisa amável sobre seus versos. E eu escrevi coisas amáveis sobre seus versos. Sejamos civilizados, sussurro. Mas ele não me escuta. De vez em quando uma ou outra das suas palavras chega com clareza. Insultos, que mais? Bicha,
}

bígua (sangue de quem?), após as ofensas desse desvelar da própria consciência pelo jovem envelhecido (a consciência que se insulta; alter ego de Bolaño ou não - é curioso que o autor tenha a mesma idade do jovem ${ }^{5}$ ), contradiz o sujeito que inicia suas memórias afirmando a necessidade de ser responsável moralmente por seus atos e silêncios (epígrafe deste artigo). Caberá às instâncias do esquecimento a ausência da responsabilidade? Ou o direito ao escape irresponsável? São questões que exigem mais tempo. Fica a ideia, entretanto, de que a memória é o inquisidor de nós mesmos. A título de enquadrar a sequência de tal exercício de memória, pode-se dizer que a narrativa se desvela em quatro episódios centrais, revistados de maneira cronológica aos eventos que os desencadeiam. São eles: a) os primeiros anos da trajetória de Lacroix, desde seu chamamento espiritual para se tornar padre até os primeiros contatos com Farewell e o mundo das letras, com o ambiente intelectual dos dândis obtusos, resumido na curta estadia na fazenda de seu preceptor; b) o episódio em que cumpre uma missão misteriosa viajando pela Europa, com a finalidade de

disse? (...) Bicha opusdeísta, disse? Depois minha cama dá um giro e não ouço mais. Como é agradável não ouvir nada. Como é agradável (...) deixar que a cama navegue governada pelos santos, entrecerrar as pálpebras, não ter memória e só ouvir o latejar do sangue" (BOLAÑO, 2009, p. 55-56).

5 A aproximação do jovem envelhecido à figura de Bolaño é uma especulação secundária, sem dúvida. Mas pode ganhar alguma relevância no viés de fortalecer a contraassinatura tramada pelo autor contra o narrador. Nesse jogo, Lacroix não teria apenas "Bolaño" contra ele, mas também o jovem envelhecido, supostamente sua consciência crítica: duas forças operando contra a voz que narra, ainda que a presença do jovem seja narrada por Lacroix mesmo. Além da opinião do jovem parecer ir em direção ao que conhecemos da postura do autor, sua idade é bastante próxima, senão a mesma: "Estávamos em fins da década de 50, e ele então devia ter somente uns cinco anos, talvez seis" (BOLAÑO, 2009, p.17), narra Lacroix de seu primeiro encontro com o jovem. Bolaño nasceu em 1953, tendo cinco ou seis anos também no final da década de 50 . 
visitar igrejas e aprender sobre seus modos de conservação - a volta ao Chile coincide com a vitória de Allende, para seu enfado, reclusão e decepção; c) o período em que dá aulas sobre o marxismo para Pinochet (já no poder via golpe) e sua cúpula militar, sob intimidação, aulas secretas a propósito das bases do pensamento marxista, episódio hilário e controverso e, por fim; d) a descrição dos saraus noturnos na casa da escritora María Canales e de seu marido norte-americano responsável por torturar perseguidos políticos da resistência nos porões da própria casa onde aconteciam esses encontros intelectuais e festivos. É marca constante, seja em qual for desses quatro eixos, o tom de conivência de Lacroix com o poder, ao poder do horror, ao estabelecido, junto a seu receio de ser acusado, ou decisivamente tentado, a fugir das ordens corretas ${ }^{6}$. À medida que esses quatro quadros se desenvolvem, acompanhamos a transformação do protagonista em seus modos de subjetivação, que, nos possíveis devires-animais encontrados no livro, partem de um Lacroix tímido, acanhado e pueril, como um passarinho, à metamorfose completa em falcão, treinado na ciência da rapinagem para caçar pombos. Quando, ainda muito jovem, é convidado para passar um final de semana na fazenda Là-bas de Farewell, o narrador se descreve como um "passarinho ingênuo que acaba de ser atraído pela grande ave de rapina que era Farewell que, com a

\footnotetext{
6 "La narrativa de Bolaño va dibujando la convivencia, la complicidad del horror con el éxito, con la no violencia, con la actualidad, con la vida normal de seres normales, con la frivolidad de lo cotidiano, con la impostación, la superficialidad o la hipocrisía de la mayoría y sus afanes de reconocimiento o de respetabilidad, incluidos los artistas (el caso más gráfico son las veladas de María Canales). Estos lugares de mal son (...) íntimamente relacionados con la sociedad consensual y despolitizada del capitalismo posthistórico" (INZAURRALDE, 2017, p. 30).
}

experiência de vida e a verborragia de um intelectual, conseguia o que desejava" (BRUNO, 2011, p.4). O episódio é ambientado num casarão de campo luxuoso, repleto de livros, num clima noir-bucólico, em que poesia, álcool, supostas orgias e eruditismo afetado disputam as vontades dos participantes ilustres. Entre eles, ironicamente, encontra-se Neruda... Em Là-bas, onde toda frase ou gesto é exagerado em prol da "ah, a imortalidade literária" - e excessivamente ridícula é a forma como Bolaño, com efeito, deseja mostrar essas cenas -, ocorre o ritual de iniciação do diletante Lacroix nesse mundo, "meu batismo no mundo das letras estava encerrado" (BOLAÑO, 2009, p. 27). Aqui o narrador é ainda o pequeno pássaro indefeso que é tocado na cintura e nas nádegas por Farewell e não reage, que se deslumbra com a pompa daqueles modos e hábitos cultos, apresentados, no entanto, como patéticos ${ }^{7}$; o Lacroix desse momento é um ínfimo adulador do já experiente falcão Farewell, seu mestre, ainda que desde então mostrasse o aceno de seu desprezo e nojo ao povo campesino que trabalhava naquela propriedade rural (assim como mostrará depois seu repúdio pelos chilenos das periferias), denotando a herança europeizada-colonizadora da qual se considera parte e chama de civilizatória. Là-bas é, por isso, um contraste de mundos. Quando convocado a dar a bênção à família de campesinos mapuches, antes da janta no casarão, lembra daqueles sujeitos de forma racista, destacando as mãos ásperas, a feiura dos rostos, a rudeza, as

\footnotetext{
“De tempos em tempos Farewell ria com sonoridade excessiva. Cada vez que rebentava uma dessas risadas, eu olhava para ele com o rabo do olho. Parecia o deus Pã, ou Baco em sua toca, ou algum demente conquistador espanhol enquisitado no seu fortim do Sul" (BOLAÑO, 2009, p. 16)
} 
palavras incoerentes, como relata: "Que bom que veio, padre, disse a mais velha, ajoelhando diante de mim e levando minha mão aos lábios. Senti medo e nojo, mas a deixei fazê-lo" (Idem, p. 16). E: "os camponeses que se afastavam eram feios, e sua singradura em ziguezague, incoerente. Deus que me perdoe e que os perdoe. Almas perdidas no deserto" (Idem, p. 26). Em dúvida se vestia a batina ou traje civil neste final de semana, Lacroix acaba por optar pela batina. Esse gesto se repete na circunstância das aulas para Pinochet. É interessante reparar que nos momentos em que o protagonista se sente menor, submisso ou então cúmplice de situações as quais não deveria pertencer ou colaborar, ele veste a roupa religiosa. Há uma frase no texto, sutil alfinetada bolañana, que pode explicar tal ocorrência: "minha batina surrada pelo vento, minha batina, que era como a minha sombra, minha bandeira negra, minha música ligeiramente engomada, roupa limpa, escura, poço onde os pecados do Chile afundavam e não saíam mais" (Idem, p.58). Camicie nere de Mussolini... Posterior a esse primeiro episódio, encontramos Lacroix, num salto de amadurecimento, sendo convidado por dois sujeitos misteriosos, Sr. Odem e Sr. Oidó, descritos praticamente como agentes de uma estrutura criminosa/militar que já elaborava em silêncio a ditadura do Chile anos mais tarde, para uma missão tão misteriosa quanto. Tais sujeitos, estranhos em todos os seus modos, portanto oferecem a Lacroix uma bolsa para passar de um ano a um ano e meio na Europa, tendo em vista que o padre conhecesse, estudasse e compusesse um relatório final sobre métodos para a conservação de igrejas em certos países do velho mundo. Essa proposta, apesar das excentricidades que a envolvem, concretiza-se para o protagonista como uma possibilidade de escape da vida entediada e arisca que andava tendo em Santiago. O aceite, os termos do contrato em pauta e as desconfianças acerca da proposição não prevista são sublimadas da narrativa, para que venhamos a encontrar já Lacroix em sua trajetória por tais igrejas. Nessa viagem, ele conhece padres com quem desenvolve relações veladas de afeto. Aqui a sinfonia é outra. Aprende com eles, durante as diversas estadias em distintos países, a arte da falcoaria, que se baseia no treinamento de aves de rapina, o falcão, em específico, para caçar pombos e evitar que suas "cagadas" impedissem a preservação das igrejas. A viagem, em si, funciona como uma suspensão no tempo para Lacroix; é quando, numa espécie de ano sabático, suas experiências e descobertas estão repletas de entusiasmo, leveza e prazer para com a vida. É evidente, no entanto, que a carga alegórica da necessidade de preservação (igrejas lidas como Chile), da importância de falcões caçarem pombos avessos a essa ordem (falcões lidos como figuras do poder opressor e conservador, pombos lidos como resistência, grupos de esquerda, progressistas em geral), "distingui, vultos informes no solo, os corpinhos ensanguentados de várias pombas, que o falcão havia depositado aos meus pés" (Idem, p. 71), fazem referência ao prenúncio do regime de exceção que está por vir, e abre espaço ao emblemático retorno de Lacroix ao Chile justamente em meio à eleição democrática de Salvador Allende e ao processo de implemento de um governo socialista inédito em toda América que afronta diretamente os ideais de nosso protagonista, que, por sua vez, entra em severa reclusão do cenário público e se 
limita, confinado, a voltar a ler os clássicos gregos enquanto aquele período não fosse encerrado. As duas páginas a propósito das impressões de Lacroix sobre a volta ao Chile são memoráveis. Num fluxo realmente verossímil ao mecanismo de uma memória que jorra, o padre mostra como a situação do país, a seus olhos, não era boa, ainda que dissesse consigo mesmo que era preciso seguir patriota. Revela na narração seu "amor autêntico" (Idem, p. 75) pelo Chile, ao passo que se debruça em refletir como o país poderia ter mudado tanto na sua ausência. "Que fizeram contigo? Os chilenos enlouqueceram? De quem é a culpa? (...) Até quando pensas continuar assim, Chile? Será que vais te transformar em outra coisa? Num monstro que ninguém mais reconhecerá?" (Idem, p. 75). Logo, Allende ganha as eleições. Enquanto a população comemora nas ruas - e inclusos nessa parcela estão diversos companheiros intelectuais de Lacroix -, Farewell e seu discípulo estão acuados. Nesse meio tempo (três anos de governo Allende, 1970-1973) que voa na narrativa, que é quase telegráfica nesta passagem, tendo praticamente a forma de tópicos como "Neruda recebeu o prêmio Nobel", "a reforma agrária expropriou a fazenda de Farewell" (Idem, p. 76-77), Lacroix está a perder-se (ou reencontrar-se em conforto) com as leituras de Tucídides, Aristóteles, Platão e outros, até que, abruptamente, a quebrar o fluxo, súbito sabemos que: “depois veio o golpe de Estado, o levante, o pronunciamento militar, bombardearam La Moneda, e, quando terminou o bombardeio, o presidente se suicidou e tudo acabou. Então eu fiquei quieto, com um dedo na página que estava lendo, e pensei: que paz" (Idem, p.77). Na rua, silêncio. Sabemos, através de um tele- fonema, que Farewell, que logo terá sua fazenda devolvida, está pulando de alegria, como é de se supor. Pois bem, o golpe de Estado, a ditadura sanguinária e brutal de Pinochet, para Lacroix, sem nenhum constrangimento, é vista como um tempo de paz, de normalidade. Ainda que reze pelos mortos no Chile, o padre da batina nera vê, não obstante, o restabelecimento da ordem, tenha o custo que tiver. Daí em diante, seu prestígio com o poder e com as elites só aumenta, ao ponto de, em determinado momento, que o pega de surpresa, aliás, ser convocado para ministrar aulas em surdina para Pinochet e sua cúpula a respeito da teoria marxista. A missão secreta é proclamada ironicamente por Sr. Odem e Sr. Oidó outra vez. Novamente estranhos, novamente omissos de detalhes e explicações. Esse terceiro movimento do enredo, isolado da sua conjuntura cruel, porque se trata de uma estratégica nítida de dominar o adversário a partir de seu próprio discurso, compreendendo-o, é muito revelador do comportamento passivo-colaborador de Lacroix. A memória do padre tenta nos convencer de certa entrega ao dever patriótico, de certa ingenuidade inclusive sobre com o que pudesse estar se envolvendo, contudo nos silêncios da narrativa é possível perceber que a conivência de Lacroix está relacionada, em última análise, a sua vontade narcísica de estar com o poder, a sua infame sede de fama, de ocupar um papel importante perante as instituições que comandam e resguardam respeito, incerta nobreza de valores, trata-se de quem se tratar. "A ingenuidade do narrador contrasta-se à ironia mordaz do autor" (COSTA, 2013, p.91). Ao final da obra ainda veremos Lacroix concretizando esse desejo, percor- 
rendo inúmeros aeroportos, pedante, dando palestras, frívolo, publicando livros. "Às vezes à noite, com a luz apagada, eu ficava sentado numa cadeira e me perguntava em voz baixa qual era a diferença entre fascista e faccioso ${ }^{8}$. Somente duas palavras. Nada mais que duas palavras" (BOLAÑO, 2009, p. 95). Lacroix, em plena metamorfose em falcão, almeja alcançar à posição que Farewell outrora ocupara; quer, vaidoso, ser visto como um erudito ilustre, e, para isso, sabe, embora não admita, que é preciso estar com a situação, e que jamais esta pode ser retrucada, desmentida. Sem dúvida a posição de homem religioso auxilia no seu engenho de esconder-se atrás das máscaras (perucas ou batinas) que precisa vestir para esquivar-se de futuras culpabilidades e pactos terroríficos; "breves infiernos de existencia semi-clandestina", como dirá Inzaurralde (2017, p. 32). É decerto essa dinâmica que o narrador esboça no gesto de apresentar suas memórias, determinante isenção de cumplicidade ao terror de Estado e suas consequências, o mal e o compartilhamento do perverso como uma dimensão desértica, mas necessária da cotidianidade. Nesse viés, é apressado afirmar que factualmente Lacroix se arrepende de seus infames envolvimentos, de que haja remorso ou ressentimento a propósito de seu colaboracionismo fascista. Há, no lugar disso, certo processo de conjuro das dúvidas que a memória reacende para tentá-lo, mas mais num sentido de um autoconvencimento de sua impecável lisura moral, de sua habilidade para lidar com problemas, do que de um

8 Do latim factiosus, diz-se do indivíduo parcial, que tem essência partidária, de facção, e é subversivo a uma ordem única estabelecida. Negativamente, pode significar injusto, ambicioso por orgulho próprio. arrependimento autoculposo. Lacroix, já artista da falcoaria, morrerá convencido de sua integridade e senso de justiça. Apesar dos momentos que abalam sua febre de reflexão, suas certezas, em geral devido às acusações do jovem envelhecido, seu vetor conclusivo aponta para uma absolvição de si, digna do homem de fé e de bem e patriota que foi; pois, afinal, sem nenhum vacilo, dirá: "O jovem envelhecido sempre esteve sozinho, e eu sempre estive com a história" (BOLAÑO, 2009, p. 116). Depois disso, tudo correrá numa velocidade de vertigem, fazendo com que os rostos e os ódios se dissolvam. No mais, as aulas para Pinochet beiram o hilário, arrancando certo tipo de riso sátiro daqueles encontros, que se somam ao constante tom pretensioso do narrador, mesmo em meio a tudo isso: um dos generais dorme, o outro se preocupa tão somente em descobrir se Marta Harnecker é uma subversiva ou é boa moça, desconhecem quem seja Althusser em plenos anos 70, dentre outros exemplos. A possibilidade real de ter havido um episódio assim na história do Chile é também pouco convincente, entretanto é preciso pensar duas vezes antes de descartar ao menos imaginá-lo, ou melhor, a potência de imaginá-lo. "Articular historicamente o passado não significa conhecê-lo 'como ele foi de fato'. Significa apropriar-se de uma reminiscência, tal como ela relampeja no momento de um perigo" (BENJAMIN, 2010a, p. 224). A verificação histórica de fontes primárias ou verídicas sobre o que a literatura diz é um problema policialesco que a história precisa, muitas vezes, livrar-se. A ficção certamente tem suas licenças e, em geral, quando bem realizadas, estas não são gratuitas. Há um empenho arquitetônico em Bolaño para provocar, pela forma literária, o limite do 
irrepresentável, um suposto pensamento impossível da besta (para mencionar a chave de leitura de Alain Badiou ${ }^{9}$ sobre o século XX, a partir do célebre poema de Osip Mandelstam, também analisado por Giorgio Agamben nessa linha), isto é, não apenas esse episódio, mas o fluxo de memória febril de Lacroix num todo, traz à tona o agenciamento material de um nãorepresentável-ainda, pois a besta, o infame, o agente do horror nunca deixou de pensar. Se ele é até-então irrepresentável, impossível de ter forma, isso significa que esse ainda-impossível precisa ser tornado possível. Esse é o movimento que opera Bolaño. Eis um gesto estritamente político, o de arrancar do impossível (que aqui é visto sempre como uma questão virtual de tempo, de um ainda-não) novas possibilidades de possível. Esse pensamento é desenvolvido extensivamente por Derrida $^{10}$, e vimos há pouco isso em relação às instâncias do dom. Juntamente, a noção de que o irrepresentável é antes de tudo uma convocação a uma nova regulagem da representação na arte, de acordo com o presente, com os novos acontecimentos de uma determinada época, é trabalhada com oportuna relevância por Jacques

9 Uma passagem que traduz a questão levantada por Badiou se encontra em "Cuestiones de método" In: El siglo, 2011, p. 15: "Decir que el nazismo no es un pensamiento o, en términos más generales, que la barbarie no piensa, equivale de hecho a poner en práctica un procedimiento solapado de absolución. Se trata de una de las formas del 'pensamiento único' actual, que es en realidad la promoción de una política única. La política es un pensamiento, la barbárie no es un pensamiento: por lo tanto, ninguna política es bárbara. Este silogismo no apunta sino a disimular la barbárie - evidente, sin embargo - del capital-parlamentarismo que hoy nos determina. Para salir de ese disimulo es preciso sostener, en y por el testimonio del siglo, que el nazismo mismo es una política, es un pensamiento".

10 Para adentrar nesse profícuo assunto em Jacques Derrida, ver seu texto pronunciado durante o seminário “Dire l’événement, est-ce possible?", de 1997, no Centro Canadense de Arquitetura: Une certaine possibilité impossible de dire l'événement, Paris: Editions I’Harmattan, 2001.
Rancière ${ }^{11}$, em Destino das imagens. É verificável facilmente a dificuldade que temos, sobretudo emocionalmente, em assumir que toda brutalidade estrutural como as que formatam os regimes de exceção, as ditaduras, o nazismo é pensante. Funciona com preparação, estratégia, não só no plano militar, superficialmente grosseiro, ou governamental-pragmático, mas, sobretudo, no plano filosófico, discursivamente articulado. Sabemos disso, no mínimo, desde Hannah Arendt. Ainda que gere raiva, náusea, desconforto, é preciso ver/encarar como esses sujeitos por trás das estruturas de exceção se articulam na dimensão pensante. A alegoria de Pinochet leitor de Marx toca, com efeito, nesta questão. Trazê-lo, ao regime das visibilidades do presente, relativamente humanizado - embora com interesses bem práticos; mostrá-lo escritor de livros, leitor, torna-se um índice não usual, mas que tem como proveito provocar as instâncias da nossa imaginação preparada, assim como nossos pressupostos metafísicos muitas vezes inconscientes. No tecido da narrativa, tanto Lacroix como Pinochet, assim como seus fantasmas secundários (Odem, Oidó, os generais, etc.) seguem monstros na relação crítica do leitor com a obra e com a história vista como um "tempo saturado de agoras", como pretendia Benjamin (2010a, p. 225), mas são monstros-pensantes, e, desse modo, são mais perigosos ainda, mais danosos do que se fossem representados nos seus convencionais papeis de objetos do mal, mudos ou indiretos, inimigos da vida ou bestas do

\footnotetext{
11 Sobre os limites do uso da noção de irrepresentável e a revisão constante das regulagens da representação na arte, ver artigo do mesmo autor publicado em Revista do IL, número 54, 2017: FARINA, Diego Lock, Disponível em: <http://seer.ufrgs.br/index.php/cadernosdoil/article/ view/67882>.
} 
inferno. Por fim, há o episódio que relata as festas literárias na casa de María Canales, as tertúlias animadas do andar de cima que ocorriam simultâneas ao encarceramento de perseguidos políticos recém-torturados no portão da mesma casa em questão. Tal imagem já sintetiza o horror e requer menos palavras. Com o toque de recolher militar, somente a afastada casa da escritora e de seu marido torturador importado Jimmy (agente do DINA) restava como ambiente para os saraus da entediada cena artística de Santiago. Lá, curiosamente, a polícia não incomodava. A descoberta ocasional dos sujeitos torturados no porão do casarão é espantosa. Anos mais tarde, quando tudo foi revelado, muitos escritores (inclusive de esquerda) negaram ter pisado lá sequer uma vez. O próprio Lacroix, em lembrança, parece querer diminuir sua assiduidade nesses eventos. A metáfora da casa é abissal: entre canapés e whisky a elite intelectual passava noites em claro em nome da arte pela arte, da celebração da vida e da hipocrisia diletante, enquanto que, no porão, o Noturno do Chile, peça musical obscura e melancólica, dava seus ares putrefatos sem, aparentemente, nenhuma dissonância. As figuras que formam na obra de Bolaño a textura do "mundo post acontecimiento pueden rastrearse en esos lugares limítrofes en los que se hace tangible el secreto del mal, lugares ambiguos donde el sadismo, la religión, la explotación, el sexo y el dinero forman uma articulación fascinante y cruel" (INZAURRALDE, 2017, p. 29). Tampouco o narrador esconde que é assim que se faz literatura no Chile e em todos os demais lugares. Pois bem, finalmente, Bolaño, com seu noturno ruidoso, parece alertar para o perigo de uma carência outra vez de nós, contemporânea, a carência de certo dom de ouvir. Um noturno, aliás, é composto para ser ouvido. Noturno do Chile tormenta, ou atormenta, na forma, a chamada de atenção para o refortalecimento de uma poética da escuta, do saber escutar para se morrer melhor e evitar que o terror, nas suas inúmeras contagens e matizes, repitase. Eco dionisíaco que ensina a ouvir também com os olhos. Arrancar sons inauditos das letras. Timpanizar o outro mais distante impossível, impossível-ainda, ainda que fraquejemos frente às tormentas de merda que nos agridem os sentidos. $E$ timpanizar, ao mesmo tempo, o autismo de nós mesmos, como alertou Derrida (1991), para que ouçamos (entendre) o infame com mais produtividade, máquina de guerra, para reagirmos a ele. Pinochet lê Marx, nós lemos Lacroix. É tarefa do século que se abre, que recém chega a sua maior idade, reaver o dom de ouvir e o senso de uma comunidade responsável pelos acordes que escuta. Os acordes - conjunto simultâneo de notas nem sempre discerníveis uma a uma - sob os quais Bolaño projeta Lacroix são intempestivos. Como disse Benjamin (2010, p. 201), "escrever um romance significa, na descrição de uma vida humana, levar o incomensurável a seus últimos limites". Talvez Bolaño nos ofereça um romance sonoro, porém também ruidoso, onde o ruído está muitas vezes nos recônditos do silêncio, que diga o horror "sem banalizá-lo pela assimilação estética realista, e, ao mesmo tempo, sem negá-lo, porque o esquecimento é um caminho propício para a repetição da barbárie" (COSTA, 2013, p. 85). Se existe uma ética pela vida que atravessa a literatura no seu encontro com a história, com a política, com o social, esta ética só se torna produtiva quando arranca um novo possível daquilo até então não 
inteligível, não imaginável, impraticável. Lacroix é sentido tão próximo a nós, e por isso tende a nos agredir simplesmente por existir como existe, não apenas porque narra suas memórias e seus silêncios hediondos em primeira pessoa, mas porque, através do exercício formal sofisticado de Bolaño, de verdadeira entrega e denúncia, sua presença impune ressona a tormenta real da história recente de um Chile avassalado pela ditadura de Pinochet, ou seja, o que torna Lacroix o infame que é para nós não é somente sua natureza verossímil, mas, sobretudo, sua precisão como sujeito possível que constitui história. A chave disso está em Benjamin (2011, p.105): "é somente quando se reconhece vida a tudo aquilo que possui história e que não constitui apenas um cenário para ela que o conceito de vida encontra sua legitimação. Pois é a partir da história (e não da natureza) que se pode ser determinado, em última instância, o domínio da vida". Trata-se da tarefa do filósofo que traduz. Talvez a sintaxe vertiginosa que Bolaño constrói em Noturno do Chile esteja mais próxima da filosofia do que da poesia propriamente dita. Uma filosofia de ruídos e silêncios, de ruídos no silêncio, pois, como bem lembraria Octávio Paz em El arco y la lira, só houve um único silêncio na história; depois deste, todos os seguintes estariam para sempre carregados de palavras ocultadas. A filosofia de Bolaño, que contra-assina o próprio narrador que cria, desvela e jorra-nos reação.

E alertas combatamos agora a tormenta de merda.

\section{Referências}

ADORNO, Theodor W. Engagement. In: Notas de literatura. Rio de Janeiro: Tempo brasileiro, 1991.

BENJAMIN, Walter. O narrador. Considerações sobre a obra de Nikolai Leskov. In: Magia e técnica, arte e política: ensaios sobre literatura e história da cultura. São Paulo: Brasiliense, 2010.

. Sobre o conceito da história. In: Magia e técnica, arte e política: ensaios sobre literatura e história da cultura. São Paulo: Brasiliense, 2010a.

A tarefa do tradutor. In: Escritor sobre mito e linguagem. São Paulo: Editora 34, 2011.

BOLAÑO, Roberto. Noturno do Chile. São Paulo: Companhia das letras, 2009.

BRUNO, Elaine Zeranze. A poeira da história: uma leitura de Noturno do Chile de Roberto Bolaño. In: Revista Garrafa, Rio de Janeiro, n. 24, s/p., maio-ago. 2011.

COSTA, Maria Iranilde Almeida. A literatura posta em questão em Noturno do Chile, de Roberto Bolaño. In: Revista Garrafa, Rio de Janeiro, n. 32, p. 85-95, out.-dez. 2013.

DERRIDA, Jacques. Essa estranha instituição chamada literatura. Belo Horizonte: UFMG, 2014.

. Une certaine possibilité impossible de dire l'événement. Paris: Editions I'Harmattan, 2001.

. Timpanizar - a filosofia. In: Margens da filosofia. Campinas: Papirus, 1991.

INZAURRALDE, Gabriel. Cuerpos semilegales: consideraciones sobre el exilado en Roberto Bolaño. In: TIMMER, Nanne (Org.). Cuerpos ilegales: Sujeto, poder y escritura en América Latina. Leiden: Almenara, 2017.

Recebido: 16 de novembro de 2018.

Aceito: 12 de dezembro de 2018.

\section{DIEGO LOCK FARINA}

Doutorando em Estudos de Literatura pela Universidade Federal do Rio Grande do Sul (D) https://orcid.org/0000-0003-0362-564X <diegolockfarina@hotmail.com> 